\title{
Comparison of Sensitivity of Autotrophic and Heterotrophic Microorganisms to the Pollution of Natural Water with Rare Earth Elements (Lanthanum and Cerium)
}

\author{
Roza A. Lozhkina', Anna S. Olkova2, Ekaterina V. Koval ${ }^{3}$, \\ Irina I. Tomilina', Maria A. Sysolyatina ${ }^{2}$ \\ 1 Papanin Institute for Biology of Inland Waters, Russian Academy of Sciences, 152742, Borok, Nekouzskii \\ region, Yaroslavl oblast, Russian Federation \\ 2 Vyatka State University, 36 Moskovskaya St, Kirov, 610000, Russian Federation \\ ${ }^{3}$ Northern Trans-Ural State Agricultural University, Agrotechnological Institute, Ulitsa Respubliki, 7, Tyumen, \\ Tyumen region, 625003, Russian Federation \\ * Corresponding author's e-mail: morgan-abend@mail.ru
}

\begin{abstract}
The purpose of the work was to compare the sensitivity of autotrophic and heterotrophic organisms used in bioassay to lanthanum and cerium under the conditions of a model experiment with aqueous media. Using bioassay methods, the pre-lethal effects of La and Ce in heterotrophic Paramecium caudatum and Escherichia coli, as well as autotrophic Chlorella vulgaris and Nostoc linckia were determined. Model solutions of $\mathrm{La}_{2}\left(\mathrm{SO}_{4}\right)_{3} \cdot 8 \mathrm{H}_{2} \mathrm{O}$ and $\mathrm{Ce}_{2}\left(\mathrm{SO}_{4}\right)_{3} \cdot 8 \mathrm{H}_{2} \mathrm{O}$ were tested in the concentration range of $0.1-200 \mathrm{mg} / \mathrm{l}$. As a result, it was shown that heterotrophic organisms are more sensitive to water pollution with $\mathrm{La}$ and $\mathrm{Ce}$ than autotrophic ones. According to the totality of experiments, cerium turned out to be more toxic than lanthanum. When planning the environmental studies of wastewater or reservoirs polluted with REE, it is recommended to focus on comparative sensitivity of bioassay methods, taking into account the test-functions used: bioassay for chemotaxis of $P$. caudatum $>$ bioassay for changes in bioluminescence of $E$. coli (strain M-17) $>$ bioassay for the content of chlorophyll a and intensity of lipid peroxidation in $N$. linckia $>$ bioassay on the increase in the number of $\mathrm{Cl}$. vulgaris.
\end{abstract}

Keywords: rare earth elements, Lanthanum, Cerium, bioassay, Nostoc linckia, Chlorella vulgaris, Paramecium caudatum, Escherichia coli.

\section{INTRODUCTION}

The extraction of rare earth elements (REE) continues to grow in proportion to the growth in production and consumption of modern electronic devices. In the areas of ore production which are rich in REE, specific pollution occurs, including the pollution of groundwaters and surface waters. The extraction of many minerals, for example, phosphates, also leads to the release of REE into the environment, since they begin to actively leach out of the waste rock, together with heavy metals [Smida et al., 2021]. Even electronic waste, such as motherboards, is becoming a real source of rare earth element pollution [Dang and Zhang, 2021]. Such anthropogenic flows of matter can be attributed to "a new type of potential anthropogenic pollution" [Itoh et al., 2021]. This process raises a number of scientific questions that scientists around the world are working on. The study of the geochemical features of REE compounds and processes of their migration in natural environments is important for understanding the contribution of these chemical elements to global environmental pollution [Canovas et al., 2020; Gonzalez et al., 2020; Fan et al., 2021]. There are works devoted to the cellular and molecular mechanisms of the toxic action of REE [Squadrone et al., 2020; He et al., 2021]. 
The standards for the content of REE in environmental components in most countries of the world have not been developed or approved at the state level [Itoh et al., 2021]. Many research teams are working on this problem. For example, American scientists have developed maximum permissible concentrations (MPCs) for Rare Earth Elements for fresh surface water [Sneller et al., 2000]. In this situation, identification of the most sensitive ecological groups and biological species to REE pollution is extremely important. The scientific data on the reactions of various living organisms to REE will make it possible to reasonably choose the bioassay methods for studying the areas with specific pollution, as well as pay more attention to sensitive groups of organisms in native ecosystems. To contribute to the solution of these issues, the purpose of the work was established - to compare sensitivity of autotrophic and heterotrophic organisms used in bioassay to lanthanum and cerium under the conditions of a model experiment with aqueous media.

\section{MATERIAL AND METHODS}

\section{Samples, chemicals and instrumentations}

The pollution of drinking water with lanthanum sulfate $\mathrm{La}_{2}\left(\mathrm{SO}_{4}\right)_{3} \cdot 8 \mathrm{H}_{2} \mathrm{O}$ and cerium sulfate $\mathrm{Ce}_{2}\left(\mathrm{SO}_{4}\right)_{3} \cdot 8 \mathrm{H}_{2} \mathrm{O}$ was simulated. Salt additions ranged from 0.1 to $200 \mathrm{mg} / \mathrm{l}$. The calculated content of $\mathrm{La}$ and $\mathrm{Ce}$ in the model solutions is shown in Table 1.

In a series of experiments with heterotrophs, bioassay of the obtained solutions was carried out according to the responses of Paramecium caudatum Ehrenberg, 1838 and Escherichia coli Migula, 1895. The culture of P. caudatum ciliates was grown under laboratory conditions on

Table 1. Correspondence of the salt concentration in the solution and the calculated REE content (mg/l)

\begin{tabular}{|c|c|c|}
\hline \multirow{2}{*}{$\begin{array}{c}\text { Correspondence } \\
\text { of salts }(\mathrm{mg} / \mathrm{l})\end{array}$} & \multicolumn{2}{|c|}{ Calculated REE content $(\mathrm{mg} / \mathrm{l})$} \\
\cline { 2 - 3 } & La & $\mathrm{Ce}$ \\
\hline 0.1 & 0.0392 & 0.0393 \\
\hline 1 & 0.392 & 0.393 \\
\hline 10 & 3.92 & 3.93 \\
\hline 50 & 19.6 & 19.65 \\
\hline 100 & 39.2 & 39.3 \\
\hline 150 & 58.8 & 58.95 \\
\hline 200 & 78.4 & 78.6 \\
\hline
\end{tabular}

the Lozin-Lozinsky mineral medium. The $E$. coli culture was purchased for bioassay in the form of a lyophilized preparation based on a conditionally non-pathogenic strain of $E$. coli M-17. The bioassay using P. caudatum is based on the comparison of the chemotaxis of ciliates in a pure (control) medium and a test medium [Environmental Regulatory Document PND F T 14.1:2:3:4.11-04. T.16.1:2:3:3.8-04, 2010]. Measurements were carried out using the "Biotester" device (Russia). When determining toxicity of solutions using bacteria, the bioluminescence of the E. coli bacterial preparation (strain M-17, manufacturer: "Immunotech", Russia) was evaluated using the "Biotoks" device (Russia) [Federal Register FR 1.39.2015.19242, 2015]. These methods provide for calculation of toxicity indices $\mathrm{T}$, converting the result of measuring the reaction into relative values (conventional units) in comparison with the control.

The unicellular green algae Chlorella vulgaris Beijer, 1890 and the cyanobacterium Nostoc linckia (Roth) Born. et Flah. were chosen as autotrophic test organisms. The culture $\mathrm{Cl}$. vulgaris was grown on the Tamiya mineral medium, and the culture $N$. linckia was grown on Gromov liquid medium № 6 without nitrogen. Cultures of autotrophs were used for bioassay in the phase of exponential growth: $\mathrm{Cl}$. vulgaris -5 days, titer $23.010^{3}$ cells $/ \mathrm{ml}, N$. linckia -5 weeks, titer 1. $1.7 \cdot 10^{7} \mathrm{cell} \mathrm{s} / \mathrm{ml}$. When determining the toxic reaction of $\mathrm{Cl}$. vulgaris, a decrease or increase in the number of algal cells was recorded in the experimental samples, as compared to the control by the direct counting method in Goryaev chamber in 72 hours of exposure [Federal Register FR 1.39.2007.03223, 2007; GOST, 2012]. In the experiments with $N$. linckia, toxicity was assessed by changes in the biochemical parameters of $\mathrm{CB}$, the exposure of $\mathrm{CB}$ to the solution of toxicants was 24 hours. The chlorophyll $a$ content in the $\mathrm{CB}$ homogenate was determined spectrophotometrically using the Specol 1300 device (Germany) [Aminot and Rey, 2000]. The intensity of lipid peroxidation (LPO) processes was also assessed spectrophotometrically by the color reaction of thiobarbituric acid with malonic dialdehyde (MDA), which is the main product of lipid oxidation [Lukatkin, 2002]. 


\section{Statistical analysis}

The experiments were carried out in 3 replicates, under laboratory conditions, in accordance with the requirements of the relevant methods. The results were processed statistically and presented as mean values and their standard deviations $(x \pm \delta)$. The significance of differences was assessed by the analysis of variance (ANOVA, LSD test) at the significance level of $p \leq 0.05$.

\section{RESULTS}

\section{Responses of heterotrophic test organisms}

The bioassays with microorganisms $P$. caudatum and E. coli are aimed at determining the pre-lethal reactions of organisms, that is why they are highly sensitive to a variety of toxicants [Olkova and Mahanova, 2018, Olkova and Berezin, 2019]. These methods are approved in Russia for the purposes of state environmental control and monitoring, so, in the conducted study, they were used to test the widest range of La and Ce concentrations (Table 2).

$P$. caudatum turned out to be more sensitive organisms than E. coli to both lanthanum and cerium. Only the samples containing 0.1 and 1 $\mathrm{mg} / \mathrm{La}$ and $0.1 \mathrm{mg} / \mathrm{l} \mathrm{Ce}$ can be called harmless to ciliates. A further increase in REE doses led to a significant increase in toxicity indices. Greater sensitivity of ciliates compared to bacteria to aluminum salts in natural water was shown earlier [Olkova and Berezin, 2021]; thus, increased sensitivity of ciliates to REE can be called natural.

Comparing the effect on ciliates of lanthanum and cerium at the concentration level of $1 \mathrm{mg} / \mathrm{l}$, it can be concluded that cerium is a more toxic element. The experiments on E. coli confirm this fact: the finding about the second group of toxicity of lanthanum was made when adding $50 \mathrm{mg} / \mathrm{l}$, while for cerium it was $10 \mathrm{mg} / \mathrm{l}$. The literature also has the information about greater toxicity of cerium in comparison with lanthanum in aqueous media. For example, the authors [Kotelnikova at al., 2019] showed that the cytogenetic effects of lanthanum for onion A. cepa under the action of cerium are manifested in the concentration range of $5-50 \mathrm{mg} / \mathrm{l}$, and under the action of lanthanum only at the doses of $10-200 \mathrm{mg} / \mathrm{l}$.

\section{Responses of autotrophic test-organisms}

Bioassays of aquatic environments by responses of unicellular green algae is regulated by international standards and accepted in the authentic form in Russia [GOST, 2012]. Cyanobacteria are more often studied as a component of natural biota, which is in ecological interaction

Table 2. Influence of lanthanum and cerium salts on the test-functions of ciliates and bacteria

\begin{tabular}{|c|c|c|c|c|c|}
\hline \multirow{2}{*}{\multicolumn{2}{|c|}{ Variant }} & \multicolumn{4}{|c|}{ Result } \\
\hline & & \multicolumn{2}{|c|}{ P. caudatum } & \multicolumn{2}{|c|}{ E. coli } \\
\hline Substance & Concentration, mg/l & Toxicity index T, c.u. & Toxicity group* & Toxicity index T, c.u. & Toxicity group* \\
\hline \multirow{7}{*}{$\mathrm{La}_{2}\left(\mathrm{SO}_{4}\right)_{3}$} & 0.1 & $-0.33 \pm 0.05$ & 1 & $-29.82 \pm 23.93$ & 1 \\
\hline & 1 & $0.25 \pm 0.05$ & 1 & $-25.18 \pm 16.42$ & 1 \\
\hline & 10 & $0.84 \pm 0.02$ & III & $-17.02 \pm 22.48$ & 1 \\
\hline & 50 & $1.00 \pm 0.00$ & III & $43.15 \pm 14.35$ & II \\
\hline & 100 & $0.99 \pm 0.01$ & III & $67.14 \pm 9.75$ & III \\
\hline & 150 & $0.99 \pm 0.01$ & III & $88.87 \pm 2.08$ & III \\
\hline & 200 & $1.00 \pm 0.01$ & III & $91.16 \pm 0.72$ & III \\
\hline \multirow{7}{*}{$\mathrm{Ce}\left(\mathrm{SO}_{4}\right)_{2}$} & 0.1 & $0.30 \pm 0.02$ & 1 & $-27.00 \pm 7.15$ & 1 \\
\hline & 1 & $0.59 \pm 0.04$ & II & $-15.60 \pm 9.93$ & 1 \\
\hline & 10 & $0.97 \pm 0.01$ & III & $42.45 \pm 3.14$ & II \\
\hline & 50 & $0.95 \pm 0.00$ & III & $97.89 \pm 0.16$ & III \\
\hline & 100 & $0.96 \pm 0.00$ & III & $98.32 \pm 0.76$ & III \\
\hline & 150 & $0.95 \pm 0.00$ & III & $97.32 \pm 0.54$ & III \\
\hline & 200 & $0.95 \pm 0.00$ & III & $97.22 \pm 0.43$ & III \\
\hline
\end{tabular}

*Note: The values corresponding to toxicity group I (non-toxic) are shown without additional highlighting. The values corresponding to toxicity group II (medium toxicity) are shown in bold. The values corresponding to the toxicity group III (high toxicity level) are shown in bold and italics. 
with satellite bacteria, which impart stability to the system that responds to anthropogenic pollution [Chakdar et al., 2012]. The potential of $\mathrm{CB}$ for bioassay is due to the presence of dosedependent biochemical reactions to heavy metals, organophosphorus substances, and pesticides [Baryla at al., 2000; Scanlan, 2001].

Determination of the response reactions of heterotrophic test organisms showed that in most cases lanthanum and cerium in the doses exceeding $10 \mathrm{mg} / \mathrm{l}$, have an effect close to the maximum. Therefore, in the experiments with autotrophic organisms, the model solutions containing 0.1 and $1 \mathrm{mg} / \mathrm{l}$ of REE salts were tested (Table 3).

Green algae $\mathrm{Cl}$. vulgaris was found to be insensitive to lanthanum and cerium in the studied concentrations. An insignificant tendency for a decrease in the number of algal cells in the solutions with REE compared to the control medium without additives was noted. This effect of lanthanum and cerium on $\mathrm{Cl}$. vulgaris is similar to the reactions of green alga Clorella fusca [Aharchaou et al., 2020].

Cyanobacterium N. linckia was found to be more sensitive to REE compared to green algae Cl. vulgaris. The measured biochemical vital factors of cyanobacteria in most cases were significantly inhibited in comparison with the control values. For example, in the solution with lanthanum concentration of $0.1 \mathrm{mg} / 1$, the content of chlorophyll $a$ in CB cells decreased by 2 times, and in a similar cerium solution - by 6.4 times. The solutions with cerium additives turned out to be more toxic in comparison with lanthanum solutions, also in terms of inhibition of intensity of lipid peroxidation, which confirms high toxicity of cerium, shown in the experiments with heterotrophic organisms.
Despite the sensitivity of $N$. linckia $\mathrm{CB}$ to the action of REE, it should be noted that the reactions of these organisms were not always proportional to the dose of the active substance. In the study of lanthanum solutions, an inversion of the CB response was observed: the dose of $0.1 \mathrm{mg} / \mathrm{L}$ La caused a decrease in intensity of lipid peroxidation, and a large dose $(1 \mathrm{mg} / \mathrm{L})$ led to the stimulation of the test-function by 2 times compared to the control. A similar inversion of reactions, although to a less extent, occurred when testing cerium solutions. Paradoxical and irregular effects are common; this phenomenon is especially characteristic when exposed to relatively low (sublethane) doses of toxicants [Erofeeva 2014].

\section{DISCUSSION}

In general, the results of the conducted studies showed that heterotrophic organisms (P. caudatum and E. coli) are more sensitive than autotrophic organisms (N. linckia and Cl. Vulgaris) to pollution of the aquatic environment with lanthanum and cerium compounds. This may be due to indirect toxic effects. For example, it was shown that La has a high affinity for phosphates, forming insoluble phosphate complexes of lanthanum, precipitated in the aqueous medium [Petersen et al., 1974; Stauber and Binet, 2000]. In the study with green algae Raphidocelis subcapitata, Petersen et al. [1974] measured the residual phosphorus and concluded that $\mathrm{LaCl}_{3}$ removed $100 \%$ of the phosphate from the induced environment. Consequently, reactions of autotrophic organisms can be associated with the effect of REE on the bioavailability of macronutrients. However, this mechanism needs to be studied separately.

Table 3. Influence of lanthanum and cerium salts on the test-functions of microalgae and cyanobacteria

\begin{tabular}{|c|c|c|c|c|}
\hline \multirow{2}{*}{\multicolumn{2}{|c|}{ Variant }} & \multicolumn{3}{|c|}{ Result } \\
\hline & & \multirow[b]{2}{*}{$\begin{array}{l}\text { Cl. vulgaris, } \\
10^{3} \text { кл. } / \mathrm{cm}^{3}\end{array}$} & \multicolumn{2}{|c|}{ N. linckia } \\
\hline Substance & $\begin{array}{c}\text { Concentration, } \\
\mathrm{mg} / \mathrm{l}\end{array}$ & & $\begin{array}{l}\text { Chlorophyll a content, } \\
\mathrm{mg} / \mathrm{ml}\end{array}$ & $\begin{array}{c}\text { LPO intensity } \\
\text { (malondialdehyde content) } \\
\mathrm{nmol} / \mathrm{ml}\end{array}$ \\
\hline \multirow{3}{*}{$\mathrm{La}_{2}\left(\mathrm{SO}_{4}\right)_{3}$} & 0 (control) & $23.0 \pm 7.4$ & $10.80 \pm 1.33$ & $0.23 \pm 0.01$ \\
\hline & 0.1 & $24.4 \pm 7.8$ & $5.02 \pm 0.71^{*}$ & $0.12 \pm 0.01^{*}$ \\
\hline & 1 & $23.2 \pm 7.4$ & $2.55 \pm 0.16^{*}$ & $0.50 \pm 0.10^{*}$ \\
\hline \multirow{3}{*}{$\mathrm{Ce}\left(\mathrm{SO}_{4}\right)_{2}$} & 0 (control) & $23.0 \pm 7.4$ & $10.80 \pm 1.33$ & $0.232 \pm 0.01$ \\
\hline & 0.1 & $23.8 \pm 7.6$ & $1.71 \pm 0.08^{*}$ & $0.05 \pm 0.01^{*}$ \\
\hline & 1 & $19.9 \pm 6.4$ & $4.27 \pm 0.08^{*}$ & $0.23 \pm 0.07$ \\
\hline
\end{tabular}

Note: Differences are significant compared with the control at $\mathrm{P} \leq 0.5$. 
Besides, the effects of REE, like many metals, often depend on the content of salts that determine water hardness. Thus, when $D$. carinata was exposed to lanthanum in soft water, the EC50 value ( 48 hours) was $43 \mu \mathrm{g} / 1$, whereas in hard water $-1180 \mu \mathrm{g} / \mathrm{L}$ [Barry and Meehan, 2000].

The maximum sensitivity of $P$. caudatum ciliates from the four tested organisms can be explained by their ability to phagocytosis as the main type of nutrition. This ensures that not only truly dissolved forms of REE enter the cell, but also that part of the toxicant molecules that is associated with organic matter or is present in the fraction of colloidal particles. For example, when lanthanum enters the environment by anthropogenic means, its main part is found in colloidal particles $(10 \mathrm{kDa})$ [Kulaksiz and Bau, 2011].

With the resorption of REE into the body and their distribution in it, other mechanisms of toxicity begin to operate. It is known that lanthanides are inhibitors of ion transport [Reed and Bygrave, 1974; Korotkov et al. 2014]. They exhibit competitive interactions with protons and basic cations $\mathrm{Ca}^{2+}$ and $\mathrm{Mg}^{2+}$, and as it was shown they interfere with $\mathrm{Ca}$ metabolism in cells due to their close ionic radii [González et al., 2015].

\section{CONCLUSIONS}

The pre-lethal responses of two heterotrophic and two autotrophic organisms to the action of REE La and Ce were evaluated. Comparing their reactions, it was found that the sensitivity of heterotrophic ciliates $P$. caudatum and bacteria $E$. coli is higher than that of autotrophic green algae $C l$. vulgaris and cyanobacteria $N$. linckia. It was taken into account that when comparing effects of $\mathrm{La}$ and $\mathrm{Ce}$, the evaluated test-functions of the experimental organisms were different, so a range of sensitivity of specific bioassay methods were built: bioassay for chemotaxis of $P$. caudatum $>$ bioassay for changes in bioluminescence of $E$. coli (strain M-17) > bioassay by the content of chlorophyll $a$ and the intensity of lipid peroxidation in $N$. linckia $>$ bioassay by increasing the number of cells $\mathrm{Cl}$. vulgaris. Cerium, when added to water in the form of $\mathrm{Ce}_{2}\left(\mathrm{SO}_{4}\right)_{3} \times 8 \mathrm{H}_{2} \mathrm{O}$, in most cases inhibited the test-functions of the organisms used more than similar additives of lanthanum.

The obtained data can be used to select bioassay methods in the case of specific pollution of waste or natural surface waters. These data also indicate the need for closer attention to populations of heterotrophic microorganisms in natural water bodies when they are contaminated with REE, since they can be inhibited in the first place, and their vital functions can serve as informative biomarkers of the REE pollution.

\section{Acknowledgements}

The authors are grateful to the phototrophic organisms Museum named after E.A. Shtina of the Department of Plant Biology, Breeding and Seed Production, Microbiology of VSATU (Russia, Kirov) for the provided cultures of cyanobacteria. This study was carried out within the framework of a State Assignment no. 121050500046-8.

\section{REFERENCES}

1. Aharchaou I., Beaubien C., Campbell P.G.C., Fortin C. 2020. Lanthanum and Cerium Toxicity to the Freshwater Green Alga Chlorella fusca: Applicability of the Biotic Ligand Model. Environmental Toxicology and Chemistry, 39(5), 996-1005. https://doi. org/10.1002/etc.4707

2. Aminot A., Rey F. 2000. Standard procedure for the determination of chlorophyll $a$ by spectroscopic methods. ICES Techniqnes in Marine Environmental Sciences: Denmark, Copengagen.

3. Barry M.J., Meehan B.J. 2000. The acute and chronic toxicity of lanthanum to Daphnia carinata. Chemosphere, 41(10), 1669-1674. doi:10.1016/ s0045-6535(00)00091-6

4. Baryla A., Laborde C., Montillet J.-L., Triantaphylides A., Chagvardie P. 2000. Evaluation of lipid peroxidation as a toxicity bioassay for plants exposed to copper. Environmental Pollution, 109, 131-135. https://doi.org/10.1016/S0269-7491(99)00232-8

5. Canovas C.R., Basallote M.D., Macias F. 2020. Distribution and availability of rare earth elements and trace elements in the estuarine waters of the Ria of Huelva (SW Spain). Environmental pollution. https://doi.org/10.1016/j.envpol.2020.115506

6. Chakdar H., Jadhav S.D., Dhar D.W., Pabbi S. 2012. Potential application of blue green algae. Journal of Scientific and Industrial Research, 71(1), 13-20.

7. Dang D.H., Zhang Z.R. 2021. Hazardous motherboards: Changes in metal contamination related to the evolution of electronictechnologies. Environmental pollution. http://doi.org/10.1016/j. envpol.2020.115731

8. Environmental Regulatory Document PND F T 14.1:2:3:4.11-04. T.16.1:2:3:3.8-04. 2010. Method for determining the integrated toxicity of surface waters, including marine, ground, drinking, waste waters, water extracts from soils, waste, sewage sludge by changes in bacterial bioluminescence 
using the "Ecolum test-system". Nera-S, Moscow

9. Erofeeva E.A. 2014. Hormesis and paradoxical effects upon exposure to pollutants. Dose-Response, 12(1), 121-135. https://dx.doi.org/10.2203\%2Fdoseresponse.13-017.Erofeeva

10. Fan X., Xue Q., Liu S.W., Tang J., Qiao J.Y., Huang Y.Y., Sun J.M., Liu N.N. 2021. The influence of soil particle size distribution and clay minerals on ammonium nitrogen in weathered crust elution-deposited rare earth tailing. Ecotoxicology and Environmental Safety. https://doi.org/10.1016/j.ecoenv.2020.111663

11. Federal Register FR 1.39.2007.03223. 2007. Method for determining the toxicity of water, water extracts from soils, sewage sludge and waste by changing the level of chlorophyll fluorescence and the number of algae cells. Akvaros, Moscow.

12. Federal Register FR 1.39.2015.19242. 2015. Environmental Regulatory Document PND F T 16.2:2.298. Methodology for determining the toxicity of samples of natural, drinking, domestic and drinking, household waste, treated sewage, waste, thawed, technological water by the express method using the Biotester device. SPEKTR-M, St. Petersburg.

13. Gonzalez R.M., Canovas C.R., Olias M., Macias F. 2020. Rare earth elements in a historical mining district (south-west Spain): Hydrogeochemical behaviour and seasonal variability. Chemosphere. https:// doi.org/10.1016/j.chemosphere.2020.126742

14. González V., Vignati D.A.L., Pons M.N., Montarges-Pelletier E., Bojic C., Giamberini L. 2015. Lanthanide ecotoxicity: First attempt to measure environmental risk for aquatic organisms. Environmental pollution, 199, 139-147. https://doi. org/10.1016/j.envpol.2015.01.020

15. GOST R 54496-2011 (ISO 8692: 2004). 2012. Water. Determination of toxicity with the use of green freshwater unicellular algae. Standartinform, Russia.

16. He X.Y., Yuan T., Jiang X.Y., Yang H., Zheng C.L. 2021. Effects of contaminated surface water and groundwater from a rare earth mining area on the biology and the physiology of Sprague-Dawley rats. Science of The Total Environment. https://doi. org/10.1016/j.scitotenv.2020.144123

17. Itoh A., Yaida A., Zhu Y. 2021. Potential Anthropogenic Pollution of High-technology Metals with a Focus on Rare Earth Elements in Environmental Water. Analytical sciences, 37(1), 131-143|. http:// dx.doi.org/10.2116/analsci.20SAR16

18. Korotkov S., Konovalova S., Emelyanova L., Brailovskaya I. 2014. $\mathrm{Y}^{3+}, \mathrm{La}^{3+}$, and some bivalent metals inhibited the opening of the $\mathrm{Tl}^{+}$- induced permeability transition pore in $\mathrm{Ca}^{2+}$ - loaded rat liver mitochondria. Journal of Inorganic Biochemistry, 141, 1-9. https://doi.org/10.1016/j.jinorgbio.2014.08.004

19. Kotelnikova A., Fastovets I., Rogova O., Volkov D.S., Stolbova V. 2019. Toxicity assay of lanthanum and cerium in solutions and soil. Exotoxicology and Environmental Safety, 167, 20-28. https://doi. org/10.1016/j.ecoenv.2018.09.117

20. Kulaksiz S., Bau M. 2011. Rare earth elements in the Rhine River, Germany: First case of anthropogenic lanthanum as a dissolved microcontaminant in the hydrosphere. Environment international, 37(5), 973979. https://doi.org/10.1016/j.envint.2011.02.018

21. Lukatkin A.S. 2002. Cold damage to heat-loving plants and oxidative stress. Publishing house of Mordov. University, Saransk.

22. Olkova A.S, Berezin G.I. 2019. Study on the sensitivity of certified bioassays to water pollution with modern herbicides: model experiments. Water and ecology: problems and solutions, 2(78), 111-119. http:// dx.doi.org/10.23968/2305-3488.2019.24.2.111-119

23. Olkova A., Berezin G. 2021. Battery of Bioassays for Diagnostics of Toxicity of Natural Water when Pollution with Aluminum Compounds. Journal of Ecological Engineering, 22(2), 195-199. https://doi. org/10.12911/22998993/131029

24. Olkova A.S., Mahanova E.V. 2018. Selection of bioassay for ecological research of water, polluted by mineral nitrogen forms. Water and ecology: problems and solutions, 4(76), 70-81. http://dx.doi. org/10.23968/2305-3488.2018.23.4.70-81

25. Petersen S.A., Sanville W.D., Stay F.S., Powers C.F. 1974. Nutrient Inactivation as a Lake Restoration Procedure - Laboratory Investigations. Report EPA660/3-74-032 ed. Corvallis, Oregon.

26. Reed K.C., Bygrave F.L. 1974. The inhibition of mitochondrial calcium transport by lanthanides and ruthenium red. Biochemistry Journal, 140, 143-155.

27. Scanlan D. 2001, Cyanobacteria: Ecology, niche adaptation and genomic. Microbiology Today, 28(3), 128-130.

28. Smida O., Souissi R., Salem M., Souissi F. 2021. Geochemical Assessment and Mobility of Undesired Elements in the Sludge of the Phosphate Industry of Gafsa-Metlaoui Basin, (Southern Tunisia). Applied Sciences. https://doi.org/10.3390/app11031075

29. Sneller F.E.C., Kalf D.F., Weltje L., Van Wezel A.P. 2000. Maximum Permissible Concentrations and Negligible Concentrations for Rare Earth Elements (REEs). RIVM report 601501 011. Rijksinstituut voor Volksgezondheid en Milieu, Netherlands.

30. Squadrone S., Brizio P., Stella C., Mantia M., Favaro L., Biancani B., Gridelli S., Da Rugna C., Abete M.C. 2020. Differential Bioaccumulation of Trace Elements and Rare Earth Elements in the Muscle, Kidneys, and Liver of the Invasive IndoPacific Lionfish (Pteroisspp.) from Cuba. Biological Trace Element Research, 196, 262-271. https://doi. org/10.1007/s12011-019-01918-w

31. Stauber J.L., Binet M.T. 2000. Canning River Phoslock field trials-Ecotoxicity testing final report. ET 317R. CSIRO Land and Water, Clayton, Australia; WA Waters and Rivers Commission, East Perth, Australia. 